\title{
Difficulties of Biology Teachers in Planning and Implementing Authentic Assessments in the 2013 Curriculum: Descriptive Studies on Biology Teachers in Senior High Schools
}

\author{
${ }^{1 *}$ Dwi Alviana Sholiha, ${ }^{2}$ Agus Ramdani, \& ${ }^{2}$ I Wayan Merta \\ Biology Education Department, Faculty of Teacher Training and Education, University of \\ Mataram. Jl. Majapahit No. 62, Mataram, Indonesia. Postal code: 83125 \\ *Corresponding Author e-mail: dwialviana39@gmail.com
}

Received: August 2021; Revised: September 2021; Published: December 2021

\begin{abstract}
This study aims to describe the difficulties of biology teachers at senior high schools (SMA) in Praya Barat Daya District for the 2020/2021 academic year in planning and implementing an authentic assessment in the 2013 curriculum. This research method uses a descriptive qualitative approach. The informants in this study were biology teachers at SMAN 1 Praya Barat Daya, biology teachers at Al Maarif Pandan Indah Islamic High School, and biology teachers at Raudlatul Ulum Islamic High School Batu Jangkih, totaling 8 people. Data collection techniques are using questionnaires, interviews, and documentation. In analyzing the data, steps were applied, namely data reduction, exposure or presentation of data and drawing conclusions. The results showed that the process of implementing an authentic assessment carried out by biology teachers was still less effective. Obtained data in planning the assessment of $78.75 \%$ included in the good category and in the implementation of the assessment obtained data of $43.26 \%$ included in the poor category. The difficulties experienced by biology teachers in planning authentic assessments of the 2013 curriculum are in determining the standard of assessment and the difficulties experienced by teachers in carrying out authentic assessments are in the affective domain.
\end{abstract}

Keywords: difficulty; planning; carrying out authentic assessment

How to Cite: Sholiha, D., Ramdani, A., \& Merta, I. (2021). Difficulties of Biology Teachers in Planning and Implementing Authentic Assessments in the 2013 Curriculum: Descriptive Studies on Biology Teachers in Senior High Schools. Prisma Sains : Jurnal Pengkajian Ilmu dan Pembelajaran Matematika dan IPA IKIP Mataram, 9(2), 163-167. doi:https://doi.org/10.33394/j-ps.v9i2.4117

\section{INTRODUCTION}

In the learning process, the teacher acts as an "actor and instructor" who fully regulates classroom life. Currently, teachers are positioned as "facilitators and motivators" who can activate and excite students to take part in classroom life (Suparto \& Liara, 2021). As a facilitator and motivator, the teacher must provide smooth learning and encourage students to be able to carry out activities and experiences in the form of observations, trials, comparisons, training, and so on so that the targeted competencies can be realized (Esi et al., 2016). The success of students is not only oriented towards results but also the learning process (Rahmawati \& Suryadi, 2019).

To find out student learning outcomes, teachers must conduct an assessment that produces information about the achievement of competencies that have been possessed by students (Hadiana, 2015). In Indonesia, a competency-based curriculum has been implemented in the form of the 2006 Curriculum and the 2013 Curriculum which was adopted due to the shift in the educational paradigm from "knowledge transfer" to "processoriented and competency-based". In achieving these competencies, it is related to knowledge, skills, experience and student learning outcomes (Subagia \& Wiratma, 2016). In addition to 
this, the problems faced in efforts to improve the assessment process and learning outcomes are from the difficulty of changing the teacher's paradigm about the assessment that should be done (Subagia, 2016).

In the 2013 curriculum, teachers must change the paradigm that is usually done. The most basic thing is about the assessment carried out on students not only on the final result, but the teacher must provide an assessment of students in all learning processes (Abduh, 2015). On the other hand, the role of the teacher has also changed from the main actor to only a facilitator and motivator. Authentic Assessment is an assessment carried out comprehensively to assess aspects of attitudes, knowledge, skills starting from the input (input), process, to the output (output) learning. Authentic assessment is natural, as it is, not under pressure (Marhaeni, 2015).

Authentic assessment is an assessment that involves students in authentic tasks that are useful, important and meaningful. Authentic assessment as one of the results of the assessment approach can be used as an alternative solution in assessing student learning development in a more comprehensive and objective manner (Kartowagiran \& Jaedun, 2016). While in Permendikbud RI No. 66 of 2013 stated that authentic assessment is an assessment carried out comprehensively to assess starting from the input (input), process, and output (output) of learning (Divanda et al., 2018). From some of these definitions, it can be concluded that authentic assessment is a form of assessment that assesses students comprehensively both in terms of attitudes, knowledge and skills from input, process to output by taking into account the overall activities carried out by students in real terms.

The implementation of Authentic Assessment in the context of the 2013 Curriculum has been expressly stated in Permendikbud No. 66 of 2013 concerning assessment standards explaining that Educational Assessment Standards are seen as criteria regarding mechanisms, procedures and instruments for assessing student learning outcomes. Educational assessment as a process of collecting and processing information to measure the achievement of student learning outcomes includes authentic assessments, self-assessments, portfolio-based assessments, daily tests, mid-semester tests, end-of-semester tests, national exams, and school or madrasa exams.

The results of the pre-research identification obtained that, the implementation of the 2013 curriculum has not been as pure as expected from the 2013 curriculum perfectly, because there is still a lack of teacher knowledge about the 2013 curriculum. Likewise in the assessment process, teachers still have difficulties so that not all types of assessment in the 2013 curriculum was used. Among these difficulties, apart from being caused by facilities and infrastructure factors, are the 2013 curriculum assessment as a complex assessment, an assessment that assesses all subjects in one theme, insufficient time and the number of students who are assessed for their various characters. From several explanations regarding the implementation of authentic assessments, researchers examined the difficulties of Biology teachers in planning and implementing authentic assessments of the 2013 Curriculum.

The purpose of this study is to analyze the difficulties of biology teachers in planning and carrying out authentic assessments on the implementation of the 2013 curriculum.

\section{METHOD}

The research method used in this study is a descriptive method with a qualitative approach. Descriptive research is research conducted to describe or explain systematically, factually and accurately about the facts and characteristics of certain populations (Sanjaya, 2014). The research was carried out in March, the even semester of the 2020/2021 Academic Year. This research was conducted at SMAN 1 Praya Barat Daya, SMA Islam Al Maarif Pandan Indah, and SMA Islam Raudlatul Ulum Batu Jangkih. The research subjects were 3 Biology teachers teaching at SMAN 1 Praya Barat Daya, 3 Biology teachers teaching at $\mathrm{Al}$ Maarif Pandan Indah Islamic High School, and 2 Biology teachers at Raudlatul Ulum Islamic High School Batu Jangkih. The total research subjects were 8 biology teachers. 
Data collection techniques used are questionnaires, interviews, and documentation. The steps applied by researchers in analyzing the data are data reduction, exposure or presentation of data and drawing conclusions. The data obtained from the questionnaire will be processed using the formula:

$$
P S=\frac{S T}{S M} \times 100 \%
$$

annotation: $\mathrm{PS}=$ score percentage $; \mathrm{ST}=$ total score $\mathrm{SM}=$ maximum score

By using this formula, a number will be obtained in the form of a percentage of the calculation results. This figure shows the success rate of the implementation of the authentic assessment carried out. The greater the number obtained, the greater the success rate of implementation or in other words effective. After the teacher's responses are calculated, then the category of teacher responses is determined with the parameters as shown in Table 1. Table 1. The success rate of implementing authentic assessment

\begin{tabular}{ccc}
\hline No & Achievement range & Criteria \\
\hline 1 & $86 \%-100 \%$ & Very good (A) \\
2 & $70 \%-85 \%$ & Good (B) \\
3 & $50 \%-69 \%$ & Enough (C) \\
4 & $1 \%-49 \%$ & Less (D) \\
\hline
\end{tabular}

\section{RESULTS AND DISCUSSION}

Based on the results of the data obtained by the authors after conducting research at Senior High School (SMA) Negeri 1 Praya Barat Daya, Islamic Private High School Al Maarif Pandan Indah, and Islamic Private High School Raudlathul Ulum Batu Jangkih about the difficulties of biology teachers in planning and implementing an authentic assessment of the 2013 curriculum through interviews, questionnaires, and documentation. It can be concluded that the biology teacher at Praya Barat Daya High School has not been optimal in planning and implementing the Authentic Assessment in three domains, namely affective, cognitive and psychomotor. Biology teachers still experience some difficulties in planning and implementing the 2013 Curriculum Authentic Assessment thoroughly in three domains because teachers do not use assessment instruments according to the 2013 curriculum assessment standards.

Biology teachers in planning authentic assessments in the lesson plan plan (RPP) are only limited to the cognitive and psychomotor domains, but there are several biology teachers at Praya Barat Daya High School who have compiled assessment instruments in three domains, namely affective, cognitive and psychomotor although not optimally, because the assessment contained in the RPP, not all of the assessment techniques in the authentic assessment have been planned. The difficulty is the teacher mentions several factors or obstacles in the preparation of the lesson plans, especially in the instrument for assessing student learning outcomes, namely socialization in schools about the 2013 curriculum is still lacking and there is a lack of understanding about the forms and techniques of Authentic Assessment, so that teachers do not have competencies that support the preparation and use of assessment instruments. Authentic.

The implementation of the Authentic Assessment of Biology teachers at Praya Barat Daya High School only applies to the cognitive domain. This is because in its implementation biology teachers have difficulty observing the affective and psychomotor domains that will be assessed because of the number of students who are not proportional in the classroom, the teaching and learning time is still lacking, the infrastructure is inadequate, the lack of cooperation between students when carrying out the assessment of the affective domain. and psychomotor, as well as the lack of discipline of students so that teachers only often use performance assessments, for example practicum in the psychomotor realm, and in the affective realm the teacher only sees cognitive results from students without using assessment 
instrument guidelines, then the affective domain will be sustainable with students who have good grades in the cognitive domain in the class.

The percentage obtained in planning an authentic assessment is $78.75 \%$, while in carrying out an authentic assessment the percentage is $43.26 \%$. Although there are several techniques and instruments that will be used but cannot be implemented during the learning process. This is caused by several factors, namely the limitation of tools, time, student discipline and the number of students. Based on the overall explanation, it can be concluded that the Biology teacher has planned and implemented the Authentic Assessment although in planning and implementing the Authentic Assessment it has not been maximized, because the assessment instruments contained in the lesson plan have not reached three domains, namely affective, cognitive and psychomotor, although there are some teachers who have arrange assessment instruments in three domains but have not been compiled and implemented optimally by Biology teachers at SMAN 1 Praya Barat Daya. This result is supported by the results of previous research (Sari et al., 2015), where in carrying out teacher assessments they still have difficulty in managing time allocation, especially in the affective and psychomotor domains, because the implementation of student competency assessments is carried out simultaneously with the learning process, while the allocation according to learning activities to explain the material, it is still lacking, it becomes an obstacle for the teacher.

Difficulties in planning authentic assessments are caused by the lack of socialization in schools about the 2013 curriculum and lack of understanding of the forms and techniques of authentic assessments, so that teachers do not have competencies that support the preparation and use of authentic assessment instruments. Difficulties in carrying out authentic assessments are in the affective domain because the number of students is not proportional. The biology teacher admits that if the teacher teaches in a class with a disproportionate number of students reaching 35 students, this causes the teacher to experience difficulties in supervision. In addition, the difficulty experienced by teachers is that in assessing observations the teacher cannot assess individually because the number of students is too large and does not match the proper ratio, so the teacher only assesses the most prominent students. For example, students who are very good or students with bad attitudes. Meanwhile, students who do not fall into this category will be included in the good category.

The difficulty of biology teachers in carrying out authentic assessments in the psychomotor realm is the lack of time allocation, due to class conditions that are more difficult to conduct, the number of students who are less than ideal per class so that the assessment becomes less objective, so the teacher only gives uniform scores to all students and facilities and infrastructure, as well as limited tools and materials to carry out practicums are also obstacles when carrying out psychomotor domain assessments. These results are in accordance with previous studies that some of the difficulties of teachers in the context of authentic assessment are in the aspects of making instruments, filling out assessment formats, difficulties in assessing student attitudes objectively (Ningrum \& Hasairin, 2017). Therefore, as a recommendation from the results of this study, a continuous training mode is needed that involves biology teachers in compiling and conducting authentic assessments in accordance with the mandate in the 2013 Curriculum. This is part of the improvement steps in the context of supervision of the implementation of the 2013 curriculum (Zulkarnen et al., 2014).

\section{CONCLUSION}

Based on the results of the research and discussion, it can be concluded that the difficulties of biology teachers in planning and implementing an authentic assessment of the 2013 curriculum at SMA Praya Barat Daya District are: a) Biology teachers have difficulty in planning Authentic Assessments, namely in determining assessment standards, such as preparing authentic assessment instruments in accordance with KD and KI 2013 curriculum are mainly affective domains, because too many aspects are assessed and will take a lot of time. b) Biology teachers have difficulty in carrying out authentic assessments in the affective 
domain, such as difficulties in implementing observation techniques, namely biology teachers often feel a lack of time in assessing students, because biology teachers must observe and assess every display of student attitudes.

\section{RECOMMENDATION}

As a recommendation from the results of this study, a continuous training mode is needed that involves biology teachers in compiling and conducting authentic assessments in accordance with the mandate in the 2013 curriculum. This is part of the improvement steps in the context of supervision of the implementation of the 2013 curriculum.

\section{ACKNOWLEDGMENT}

This study is a research project as a final assignment in biology education study program, University of Mataram. The author would like to thank the supervisors, and the parties involved in this research.

\section{REFERENCES}

Abduh, M. (2015). Pengembangan Media Pembelajaran Tematik- Integratif berbasis Sosiokultural bagi Siswa Kelas IV Sekolah Dasar. Profesi Pendidikan Dasar, 2(2), 121-132.

Arikunto, S. (2013). Prosedur Penelitian suatu Pendekatan Praktik. Jakarta: Rineka Cipta.

Divanda, A. D., Suwandi, S., \& Hastuti, S. (2018). Implementasi Penilaian Autentik dalam Kurikulum 2013 pada Pembelajaran Bahasa Indonesia (Studi Kasus di SMA Negeri 1 Gemolong). BASASTRA: Jurnal bahasa, Sastra dan Pengajarannya, 6(2), 1-9.

Esi, E., Purwaningsih, E., \& Okianna. (2016). Peranan Guru sebagai Fasilitator dan Motivator dalam Meningkatkan Hasil Belajar di Kelas XI SMK. Jurnal Pendidikan Dan Pembelajaran Khatulistiwa, 5(10), 1-14.

Hadiana, D. (2015). Penilaian Hasil Belajar untuk Siswa Sekolah Dasar. Jurnal Pendidikan dan Kebudayaan, 21(1), 15-26.

Kartowagiran, B., \& Jaedun, A. (2016). Model asesmen autentik untuk menilai hasil belajar siswa sekolah menengah pertama (SMP): Implementasi asesmen autentik di SMP. Jurnal Penelitian Dan Evaluasi Pendidikan, 20(2), 131-141.

Marhaeni, A. A. I. N. (2015). Asesmen Autentik dan Pendidikan Bermakna: Implementasi Kurikulum 2013. JPI (Jurnal Pendidikan Indonesia), 4(1). 499-511.

Ningrum, N. A., \& Hasairin, A. (2017). Analisis Kesulitan Pelaksanaan Penilaian Autentik dalam Pembelajaran Biologi pada Kurikulum 2013 di SMA Negeri Kota Binjai. Jurnal Pelita Pendidikan, 6(1), 20-27.

Rahmawati, M., \& Suryadi, E. (2019). Guru sebagai fasilitator dan efektivitas belajar siswa. Jurnal Pendidikan Manajemen Perkantoran (JPManper), 4(1), 49-54.

Sari, E. N., Rosyidatun, E. S., \& Juanengsih, N. (2015). Profil Penilaian Otentik pada Konsep Biologi di SMA Negerikota Tangerang Selatan. Jurnal Penelitian dan Pembelajaran IPA, l(1), 1-26.

Subagia, I. W. (2016). Perubahan Paradigma Penilaian Hasil Belajar sebagai Upaya Peningkatan Mutu Pembelajaran Sains. 8, 1-9.

Subagia, I. W., \& Wiratma, I. G. L. (2016). Profil Penilaian Hasil Belajar Siswa Berdasarkan Kurikulum 2013. JPI (Jurnal Pendidikan Indonesia), 5(1), 39-55.

Suparto, S., \& Liara, H. R. (2021). Peran Guru PAI sebagai Motivator Dalam Membentuk Perilaku Islami Peserta Didik di SDN Mawomba Kecamatan Tojo Barat Kabupaten Tojo Una-Una. Guru Tua : Jurnal Pendidikan Dan Pembelajaran, 4(1), 51-58.

Zulkarnen, W., Setyowati, A. J., \& Mahanal, S. (2014). Masalah guru dalam implementasi kurikulum 2013 dan kerangka model supervisi pengajaran. Managemen Pendidikan, 24(3), 213-220. 